University of Rhode Island

DigitalCommons@URI

The Rhode Island Current Conditions Index

Economics

8-2017

\title{
Rhode Island Current Conditions Index - August 2017
}

Leonard Lardaro

University of Rhode Island, lardaro@uri.edu

Follow this and additional works at: https://digitalcommons.uri.edu/ricci

Part of the Econometrics Commons

Terms of Use

All rights reserved under copyright.

\section{Recommended Citation}

Lardaro, Leonard, "Rhode Island Current Conditions Index -- August 2017" (2017). The Rhode Island Current Conditions Index. Paper 164.

https://digitalcommons.uri.edu/ricci/164

This Article is brought to you for free and open access by the Economics at DigitalCommons@URI. It has been accepted for inclusion in The Rhode Island Current Conditions Index by an authorized administrator of DigitalCommons@URI.For more information, please contact digitalcommons-group@uri.edu. 


\title{
CURRENT CONDITIONS
}

LEONARD LARDARO, URI

\author{
Available Online: http:/ / www.Ilardaro.com/ current.htm \\ Blog: http:/ / rieconomy.blogspot \\ Twitter: @ladardo
}

VOL XXLV

NUMBER 9

AUG 2017
Rhode Island's enhanced economic momentum continued in August, as we are now well on the way to restoring the economic growth trajectory we were on at the end of 2015. The August Current Conditions Index value remained at 83 , as ten of its twelve indicators improved. Importantly, the $\mathrm{CCl}$ beat its yearearlier value for the eighth consecutive time this year, a feat that hasn't occurred for a very, very long time. In absolute terms, the outperformance of our state's economy relative to each month last year is very impressive, something we almost never see here. In relative terms, we have been comparing to a somewhat flat economy in the first two quarters of 2016. That is why the most recent two months, July and August, provide us with "fresh" data, in the sense of being post-flat economy results. Thus far Rhode Island has impressed in the third quarter, even though comps have not exactly been all that difficult.

I continue to pay particular attention to two economic statistics both of which are survey based. The first of these, payroll employment, represents the number of jobs in Rhode Island. Over the past four months, year-over-year changes in this measure have become noticeably larger, at just under two percent on an annual basis in August. In an attempt to corroborate this, I have sought to ascertain whether the recent employment trend is consistent with the behavior of income tax withholding, which is not survey based. If the sudden surge in payroll employment growth is to be believed, I expect withholding to be rising rapidly as well. While that was the case

\begin{tabular}{|l|r|r|}
\hline \multicolumn{3}{|c|}{ CCI Indicators - \% Change } \\
\hline Government Employment & $\mathbf{- 1 . 0}$ & \\
\hline US Consumer Sentiment & $\mathbf{7 . 8}$ & Y \\
\hline Single-Unit Permits & $\mathbf{8 3 . 2}$ & Y \\
\hline Retail Sales & $\mathbf{8 . 6}$ & Y \\
\hline Employment Services Jobs & 0.0 & \\
\hline Priv. Serv-Prod Employment & 2.2 & Y \\
\hline Total Manufacturing Hours & 6.7 & Y \\
\hline Manufacturing Wage & 4.2 & Y \\
\hline Labor Force & 0.7 & Y \\
\hline Benefit Exhaustions & -28.0 & Y \\
\hline New Claims & -14.6 & Y \\
\hline Unemployment Rate (change) & -1.0 & Y \\
\hline \multicolumn{2}{|c|}{ Y = Improved Value } \\
\hline
\end{tabular}

for May through July, it is not true for August: Payroll employment growth appeared to surge to 1.9 percent (annually) in August, but income tax withholding actually fell by 0.3 percent (both seasonally adjusted). So, while it is very likely that payroll employment growth has accelerated recently, it is reasonable to expect that its growth might not be as favorable as existing data now show. Of course, we will have to wait until data revisions in February to be sure. thing that we left behind in the last recovery, it was our state's
The second metric is Rhode Island's Labor Force. If there is one

Labor Force, which has displayed a very well-defined down trend since January of 2007 something I view as a train wreckuntil the last six months that is. On both a monthly and year-over - year basis, our Labor Force appears to have been improving since 2017 began. While this might turn out to be correct when data revisions are made, it might also prove to be "déjà vu" all over again - we witnessed exactly the same pattern last year, which was ultimately revised away. Until proven otherwise, remain somewhat skeptical about the recent improving trend in our state's Labor Force.

Returning to August's performance, four of the five leading indicators contained in the $\mathrm{CCl}$ improved, although all had very easy "comps" a year ago. The one indicator whose recent performance continues to concern me, Employment Service Jobs, an indicator that includes temporary employment and is a leading indicator of future employment, failed to improve again in August. It has now improved only once (July) since March of 2016. Clearly, this indicator remains in a downtrend.

New Claims, the timeliest measure of layoffs, fell once again in August $(-14.6 \%)$, registering its eighth improvement in the last ten months. Along with this, both of the goods-producing leading indicators contained in the CCl improved significantly. SingleUnit Permits, which reflects new home construction, rose by a amazing 83.2 percent, thanks in part to an easy comp last August. Total Manufacturing Hours, a proxy for manufacturing output, the other goods-producing indicator, rose by a robust 6.7 percent (also an easy comp). Finally, US Consumer Sentiment improved in August $(+7.8)$, its tenth-consecutive increase.

Government Employment fell slightly from a year ago (-1.0\%) Private Service-Producing Employment growth accelerated $(+2.2 \%)$, while Retail Sales rose by a healthy 8.6 percent after falling last month. Benefit Exhaustions, which reflects longerterm unemployment, fell by 28 percent in August, as its long-term downtrend remains intact. Finally, our Labor Force trend, Rhode Island's train wreck, improved again in August - six in a row now. Once again, our Unemployment Rate fell (relative to a year ago) for the right reasons.

$\begin{array}{rrr}\text { LABOR FORCE: } & \text { Aug 2017 } & \text { Peak (1/ 2007) } \\ \text { Participation Rate } & 64.6 \% & 68.6 \% \\ \text { Employment Rate } & 61.9 \% & 65.4 \%\end{array}$
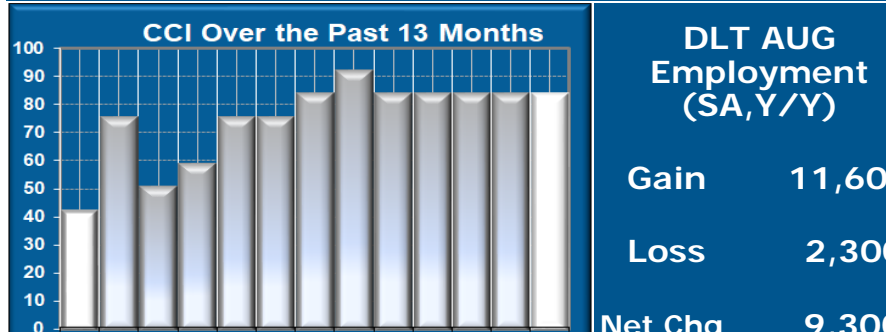

Gain

11,600

Loss

2,300

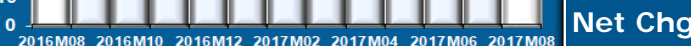

9,300

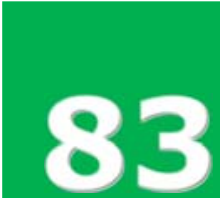

\begin{tabular}{|l|l|l|l|l|}
\hline & Jan & Feb & Mar & Apr \\
\hline 2016 & $50 \downarrow$ & $58 \downarrow$ & $58 \uparrow$ & $33 \downarrow$ \\
\hline 2017 & 75 & 83 & 92 & 83 \\
\hline
\end{tabular}

\begin{tabular}{|c|c|c|c|c|c|c|c|}
\hline May & J un & J ul & Aug & Sep & Oct & Nov & Dec \\
\hline 50 & 42 & $58 \downarrow$ & $50 \downarrow$ & 75 & $50 \downarrow$ & $58 \downarrow$ & $75 \downarrow$ \\
\hline 83 & 83 & 83 & 83 & & & & \\
\hline
\end{tabular}

